\title{
Application of rRNA-Based Probe for Detection of a Bacterium in Rhizoplane
}

\author{
Masaya Nishiyama, Yoshitaka Shiomi, and Takuya Marumoto \\ Faculty of Agriculture, Yamaguchi University, Yamaguchi, 753 Japan
}

Received July 29, 1996; accepted in revised form December 19, 1996

\begin{abstract}
Recently, in situ hybridization technique targeted to ribosomal RNA (Delong et al. 1989) has been widely used to detect specific microorganisms in various environments such as marine environment (Nishimura 1995), sediments (Spring et al. 1993), inside of organisms (Amann et al. 1991), and soil (Hahn et al. 1992). This technique provides information not only on microscale localization of the microorganisms but also on their metabolic activities in situ. So far, detection by in situ hybridization targeted to ribosomes in soil has been scarcely reported because two problems arise when this method is applied to soil. The first is that cells in natural soils cannot be easily stained because the cellular ribosome content is low in an oligotrophic soil environment. The second is that non-specific binding of the probes to soil particles and autofluorescence of soil components such as organic matter and mineral particles interfere with the signal from the probe specifically hybridized.

In this study, three experiments were carried out to investigate the applicability of in situ hybridization technique with a rRNA-based oligonucleotide probe for the detection of bacterial cells. The first aimed at analyzing the effects of starvation on the detection of a bacterium and the applicability of this method for oligotrophic environment. The second aimed at observing the interference of soil components. Finally, since the rhizoplane is copiotrophic in the soil environment, applicability of in situ ribosomal staining for detection of a bacterium in the rhizoplane was evaluated.
\end{abstract}

\section{Materials and methods}

Bacterial strain and preparation of the samples. Pseudomonas fluorescens IAM $12022^{\mathrm{T}}$ was used as target microorganism in this study. The bacterium was grown at $27^{\circ} \mathrm{C}$ in a nutrient broth (Difco Nutrient Broth $8 \mathrm{~g} \mathrm{~L}^{-1}, \mathrm{NaCl} 5 \mathrm{~g} \mathrm{~L}^{-1}$ ) to the exponential growth phase. The bacterial cells were harvested by centrifugation $(4,150 \times g, 5 \mathrm{~min})$, washed twice with sterilized $0.1 \mathrm{M}$ phosphate buffer $(\mathrm{pH} 7.2)$, and resuspended in sterilized mineral solution $\left(\mathrm{K}_{2} \mathrm{HPO}_{4} 0.5 \mathrm{~g}, \mathrm{NaNO}_{3} 0.5 \mathrm{~g}, \mathrm{MgSO}_{4} \cdot 7 \mathrm{H}_{2} \mathrm{O} 0.2 \mathrm{~g}, \mathrm{FeSO}_{4} \cdot 7 \mathrm{H}_{2} \mathrm{O}\right.$ trace, deionized water $1,000 \mathrm{~mL}, \mathrm{pH} \mathrm{7.2)}$ to obtain a concentration of approximately $10^{9}$ cells $\mathrm{mL}^{-1}$. To prepare the starved cells, $5 \mathrm{~mL}$ aliquots of the bacterial suspension were transferred to test tubes and incubated at $27^{\circ} \mathrm{C}$ without addition of substrates. The number of bacteria was periodically determined by direct microscopic counting after staining with ethidium bromide (EB) (Someya 1995), 2-( $p$-iodophenyl)-3-( $p$-nitrophenyl)-5-phenyl tetrazolium chloride (INT) (Zimmermann et al. 1978) or in situ hybridization and by plate counting.

To determine the interference of soil components, $90 \mathrm{~mL}$ of the mineral solutions

Key Words: detection of microorganisms, in situ hybridization, Pseudomonas fuorescens, rhizoplane bacteria, whole-cell hybridization. 
containing the bacterial cells were mixed with $10 \mathrm{~g}$ of sterilized soil (Red-Yellow soil, collected from Yamaguchi University Farm, total carbon $2.2 \%$, total nitrogen $0.21 \%$, clay loam). The bacterial cells in the suspension were enumerated by direct microscopic counting after staining with EB or in situ hybridization.

For root samples, tomato seedlings were allowed to germinate on moist filter paper and grown in a chamber under controlled temperature of $27^{\circ} \mathrm{C}$ and a $12 \mathrm{~h} \mathrm{light} / 12 \mathrm{~h}$ dark cycle for $10 \mathrm{~d}$. The bacterial cells in the exponential growth phase or starved in mineral solution for $65 \mathrm{~d}$ were harvested, washed, and resuspended in mineral solution as described above. The roots of the seedlings were immersed in the bacterial suspension, and the seedlings were grown on the moist filter paper in a chamber under controlled environment for $5 \mathrm{~d}\left(27^{\circ} \mathrm{C}\right.$, $12 \mathrm{~h}$ light $/ 12 \mathrm{~h}$ dark). Then, the roots were washed twice by gentle shaking in PBS buffer $\left(0.13 \mathrm{M} \mathrm{NaCl}, 7 \mathrm{mM} \mathrm{Na} \mathrm{HPO}_{4}, 3 \mathrm{mM} \mathrm{NaH} \mathrm{PO}_{4}, \mathrm{pH} 7.2\right)$ for $5 \mathrm{~min}$ and fixed.

Cell fixation and in situ hybridization. The cell suspensions with or without soil particles were diluted with phosphate buffer $(0.1 \mathrm{M}, \mathrm{pH} 7.2)$, fixed in $4 \%$ paraformaldehyde/ $1 \times$ PBS for $5-16 \mathrm{~h}$ at $4^{\circ} \mathrm{C}$, washed with $1 \times$ PBS, and filtered through a $0.2 \mu \mathrm{m}$, black stained, polycarbonate filter (Amann et al. 1990). The filters were placed on glass slides and air-dried.

Roots were fixed in $4 \%$ paraformaldehyde $/ 1 \times$ PBS for $5-16 \mathrm{~h}$ at $4^{\circ} \mathrm{C}$, washed with $1 \times$ PBS, and air-dried. Then, the roots were cut into pieces 10 to $15 \mathrm{~mm}$ in length, and mounted on gelatin-coated slides ( $0.1 \%$ gelatin, $\left.0.01 \% \mathrm{KCr}\left(\mathrm{SO}_{4}\right)_{2}\right)$ with PapPen (COSMO BIO, Japan).

After being dried, the samples were treated with lysozyme $(0.1 \mathrm{M}$ Tris- $\mathrm{HCl} \mathrm{pH} 7.5,5 \mathrm{~mm}$ EDTA pH 8.0, lysozyme $1 \mathrm{mg} \mathrm{mL}^{-1}$ ) (Hahn et al. 1993) for $30 \mathrm{~min}$ at $25^{\circ} \mathrm{C}$ and washed in $0.1 \%$ Nonidet P-40 at room temperature for $3 \mathrm{~min}$. After dehydration in 50 and $80 \%$ ethanol, the slides were washed in $1 \%$ toluene/99.5\% ethanol and $99.5 \%$ ethanol for 3 min each and air-dried.

The air-dried samples were prehybridized with $50 \mu \mathrm{L}$ of hybridization buffer $(0.9 \mathrm{M}$ $\mathrm{NaCl}, 20 \mathrm{~mm}$ Tris- $\mathrm{HCl} \mathrm{pH} 7.5,0.01 \%$ SDS, $5 \mathrm{~mm}$ EDTA) and incubated for $30 \mathrm{~min}$ at the same temperature as for hybridization $\left(46\right.$ or $\left.50^{\circ} \mathrm{C}\right)$. After the buffer was removed, the samples were treated with $4 \mu \mathrm{L}$ of hybridization buffer containing one of the following oligonucleotide probes (final concentration of $10 \mathrm{ng} \mu \mathrm{L}^{-1}$ ); 1) Eub338 (specific for all eubacteria, complementary to positions 338 to 355 of the 16S rRNA Escherichia coli numbering) (Giovannoni et al. 1988), 2) Ps (specific for fluorescent pseudomonads except Pseudomonas putida, complementary to positions 1,432 to 1,446 of the $23 \mathrm{~S}$ rRNA $E$. coli numbering) (Schleifer et al. 1992), 3) Pf1432 (5'-GCTGGCCCTAGCCTTC-3', one base (underlined) was inserted into Ps. We used this probe as negative control in this experiment). All the probes were labeled with tetramethylrhodamin-isothiocyanate (TRITC) (excitation wavelength $547 \mathrm{~nm}$, emission wavelength $572 \mathrm{~nm}$ ) at the $5^{\prime}$-end. The samples were covered with micro-coverglasses and hybridized for 2 or $5 \mathrm{~h}$ at 46 or $50^{\circ} \mathrm{C}$ in a moist chamber. After hybridization, the slides were washed in hybridization buffer to remove excess probes for 20 or $60 \mathrm{~min}$ at 48 or $50^{\circ} \mathrm{C}$, rinsed with sterile water, and air-dried. The slides were stored at $4^{\circ} \mathrm{C}$ in the dark until observation and examined with an epifluorescence microscope (OLYMPUS BX40, Japan) equipped with 2 filter sets, U-MWIG (excitation wavelength $520-550 \mathrm{~nm}$, for observation of TRITC-derived fluorescence) and U-MWIB (excitation wavelength 460-490 $\mathrm{nm}$, by which TRITC molecules are not excited). Color micrographs were taken on FUJICHROME PROVIA 1600. Exposure times were $15 \mathrm{~s}$. 


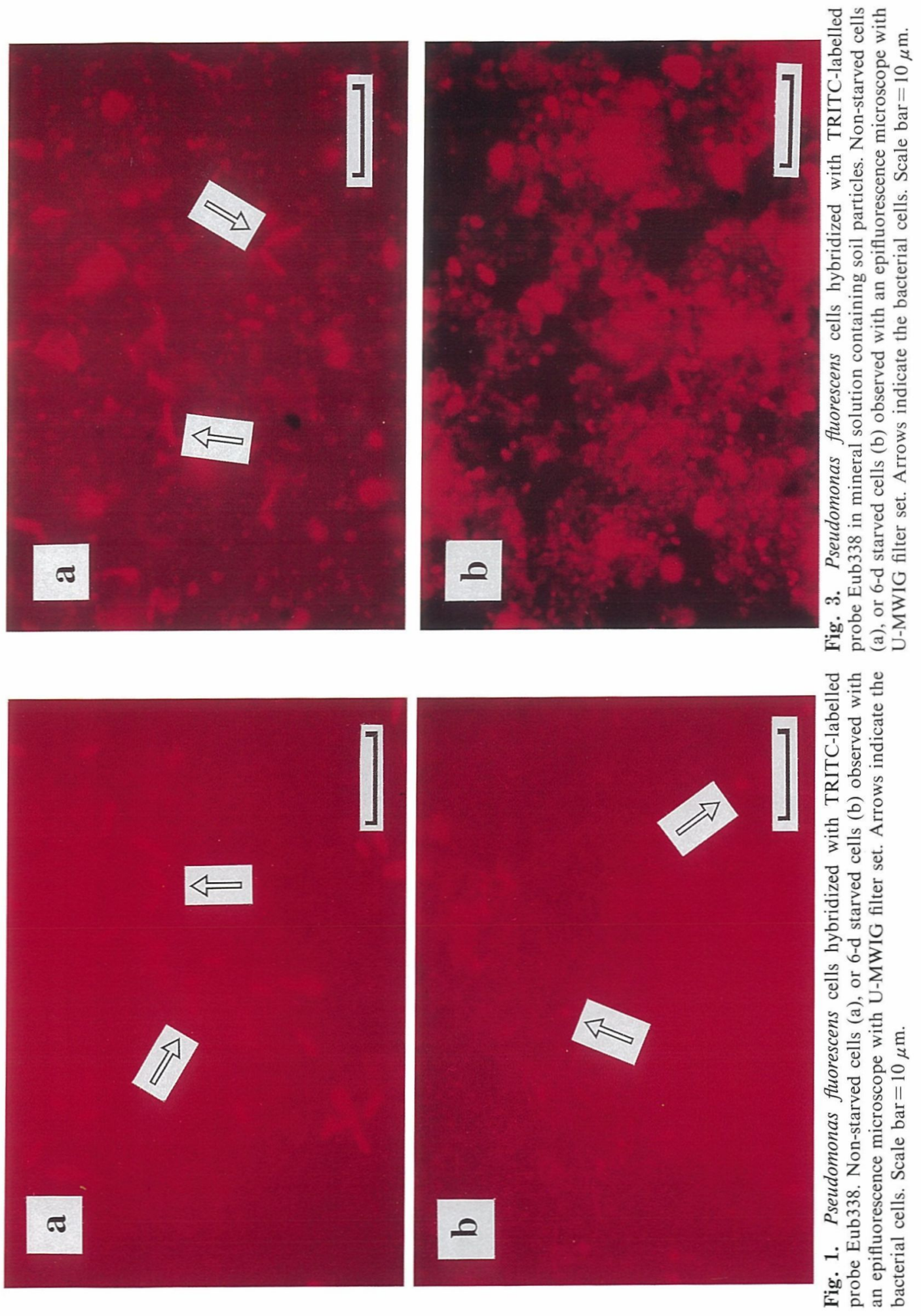




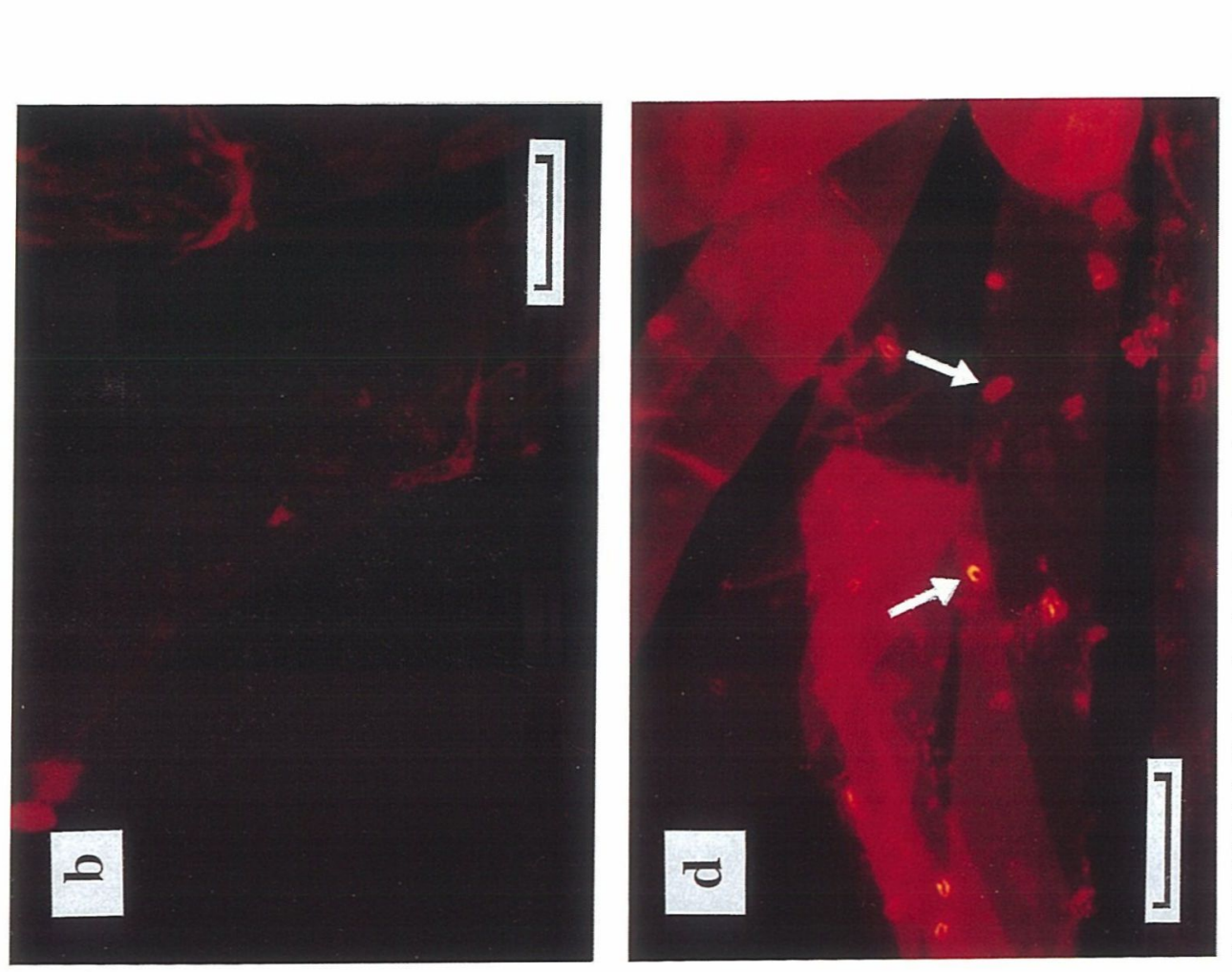

กิ่

ธ。 ฏ

ว.

인

刃

可

t

क

ㄷํㅇำ

$z \cong 8$

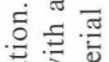

$\frac{\pi}{0}$

उ. ฮ

링

政

巳 응

ఫ先:

in $\Xi$

¿ :

$\circ$ ำ

흔

马于

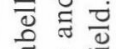

눈

U

䠌

든

ㅎํㅇ

วิ
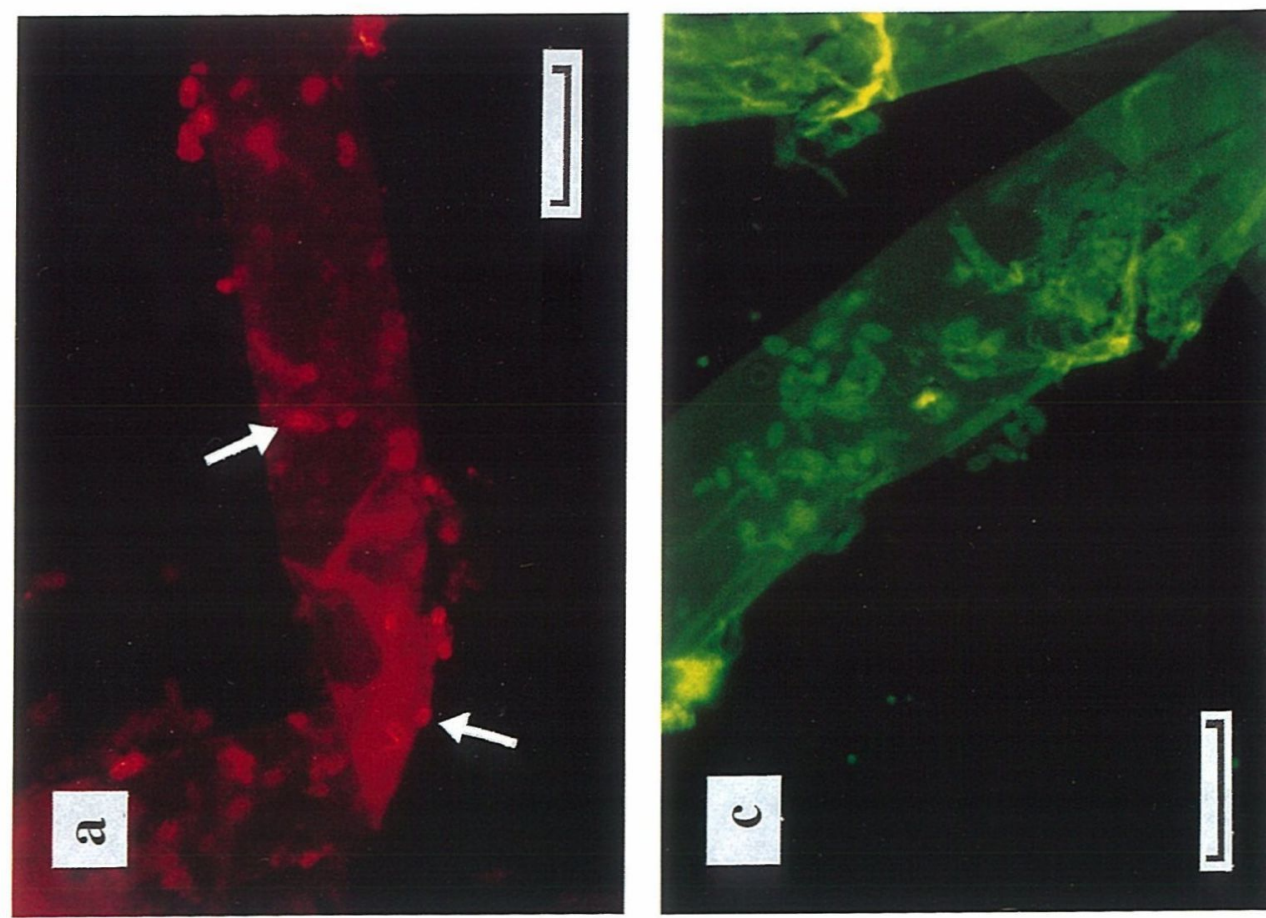

氜 可

율

i 0

은

है

อ 30

. ్ㅡㄹ

음

는.

훙

¿

施

$\therefore$ ०

ㄷํㅇ

¿

霡

¿ें

ธ。

चे

윯 Ð

บ्]

प्व

030

퓨워 के ठ

मํ 这焉息 


\section{Results and discussion}

Detection of bacterial cells in mineral solution and soil suspension. P. fluorescens cells cultured in mineral solution were periodically stained with the probe Eub338 (hybridization $46^{\circ} \mathrm{C} 2 \mathrm{~h}$, washing $48^{\circ} \mathrm{C} 20 \mathrm{~min}$ ). The fluorescence intensity of non-starved cells (immediately after being transferred to the mineral solution) was strong enough for detection with the epifluorescence microscope (Fig. 1a). When hybridized with a negative probe, Pf1432, the bacterial cells were not stained (data not shown). Therefore, it was concluded that the bacterium can be stained with Eub338, an appropriate rRNA-targeted probe, under these hybridization conditions.

As the duration of the incubation period in the mineral solution increased, the fluorescence intensity decreased (Fig. 1b). Similar results were obtained in soil by Hahn et al. (1992). At $65 \mathrm{~d}$ after incubation, the fluorescence intensity became close to the detection limit. The number of probe-hybridized cells was nearly equal to that by EB staining or by plate counting at the start of incubation (Fig. 2). The number of probe-hybridized cells decreased until $20 \mathrm{~d}$ after incubation and thereafter became almost constant. Similarly, the number of INT-stained cells decreased at first, and reached a constant level, whereas the number determined by plate counting decreased during the incubation period and that by EB staining was nearly constant after $3 \mathrm{~d}$ of incubation. These results suggest that ribosomal staining enables to detect metabolically active cells as in the case of INT-staining and the culture method. The detection efficiency of this bacterium by ribosomal staining was equivalent to that by the INT method and higher than that by the plate counting method.

P. fluorescens cells in the mineral solution containing soil particles were also subject to hybridization with probe Eub338 (hybridization $46^{\circ} \mathrm{C} 2 \mathrm{~h}$, washing $48^{\circ} \mathrm{C} 20 \mathrm{~min}$ ). The fluorescent signals of the non-starved cells were strong and allowed to distinguish them from soil particles (Fig. 3a). In 6-d starved cells, however, the fluorescent signals of probehybridized cells became weaker and it was difficult to distinguish the cells from soil particles (Fig. 3b). To detect starved cells, addition of nutrients to increase the cellular ribosome content (Hahn et al. 1992; Nishimura et al. 1995) or separation of the cells from soil particles before observation will be necessary.

Detection of bacterial cells in rhizoplane. In the soil environment, the rhizosphere is rich in substrates and bacterial cells there are expected to be more active and contain a

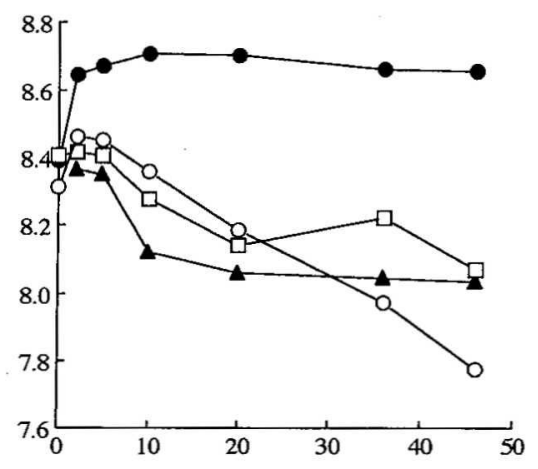

Incubation period (days)
Fig. 2. Number of Pseudomonas fuorescens in mineral solution determined by $\bullet$, ethidium bromide staining; $\square$, in situ hybridization; 0 , plate counting; $\mathbf{\Delta}$, INT staining. 
larger number of ribosomes. In addition, there are fewer soil particles in the rhizoplane, which is favorable for the detection. When the non-starved cells were introduced onto roots and subject to fixation and hybridization under the same conditions as in the mineral solution (hybridization $46^{\circ} \mathrm{C} 2 \mathrm{~h}$, washing $48^{\circ} \mathrm{C} 20 \mathrm{~min}$ ), the fluorescent signal of the Eub338- and Ps-stained cells was strong enough for the detection. However, when hybridized with a negative probe, Pf1432, some of the cells fluoresced as strongly as Eub338- or Ps-hybridized cells. Treatments with $\mathrm{H}_{2} \mathrm{O}_{2}$ (Hahn et al. 1993) or $\mathrm{NaBH}_{4}$ (Ramsing et al. 1993) were attempted to remove organic compounds in the rhizoplane which might cause nonspecific binding of the probes, but the fluorescence intensity of the Pf1432-stained cells did not decrease in this experiment. To reduce the false signal when cells were hybridized with the Pf1432 probe, hybridization and washing temperature was raised to $50^{\circ} \mathrm{C}$ and washing time was extended to $1 \mathrm{~h}$. In addition, hybridization time was extended to $5 \mathrm{~h}$ to enhance the fluorescence intensity of the Eub338- and Ps-hybridized cells by increasing the permeability of the probe. Under these conditions, the bacterial cells fluoresced strongly enough to be detected when hybridized with Ps (Fig. 4a) and Eub338 (not shown), while they scarcely fluoresced when hybridized with the negative probe, Pf1432 (Fig. 4b). Strong fluorescent signals in hybridization with Pf1432 were probably due to autofluorescence because the fluorescence observed with the U-MWIG filter set (Fig. 4b) was also observed with the U-MWIB filter set (Fig. 4c) with which TRITC molecules are not excited. These results indicate that optimal conditions for staining were different between the cells on the filter and those in the rhizoplane.

When the cells starved for $65 \mathrm{~d}$ were used as an inoculant and stained after $5 \mathrm{~d}$ of culture on the seedlings, the cells in the rhizoplane fluoresced strongly enough to be detected (Fig. $4 d)$. This fact indicates that even if the bacterial cells were initially starved and were not stained by ribosomal hybridization, they became metabolically active and detectable after reaching the rhizoplane.

Figure $4 \mathrm{a}$ and $\mathrm{d}$ shows that the fluorescence intensities differed among the cells, indicating that some cells are more active than others on the same root hair. Ribosomal staining technique might provide information on the microscale localization of physiologically different bacterial cells in rhizoplane.

In conclusion, in this experiment, ribosomal staining was found to offer a potential to detect bacterial cells in the rhizoplane in situ. However, the application of in situ detection with fluorescent probes was limited to the root hair zone. The cells in the main root zone could not be detected due to the strong fluorescence of the root. By using a confocal laser scanning microscope, this problem of background fluorescence of thick roots might be solved (Assmus et al. 1995).

Acknowledgments. This research was supported in part by a Grant-in-Aid for Scientific Research from the Ministry of Education, Science, Sports and Culture of Japan (No. 07660085).

\section{REFERENCES}

Amann, R.I., Binder, B.J., Olson, R.J., Chisholm, S.W., Devereux, R., and Stahl, D.A. 1990: Combination of $16 \mathrm{~S}$ rRNA-targeted oligonucleotide probes with flow cytometry for analyzing mixed microbial populations. Appl. Environ. Microbiol., 56, 1919-1925

Amann, R.I., Springer, N., Ludwig, W., Gortz, H.D., and Schleifer, K.H. 1991: Identification in situ and phylogeny of uncultured bacterial endosymbionts. Nature, 351, 161-164

Assmus, B., Hutzler, P., Kirchhof, G., Amann, R.I., Lawrence, J.R., and Hartmann, A. 1995: In situ 
localization of Azospirillum brasilense in the rhizosphere of wheat with fluorescently labeled, rRNAtargeted oligonucleotide probes and scanning confocal laser microscopy. Appl. Environ. Microbiol., 61, 1013-1019

Delong, E.F., Wickham, G.S., and Pace, N.R. 1989: Phylogenetic stains: ribosomal RNA-based probes for the identification of single cells. Science, 243, 1360-1363

Giovannoni, S.J., Delong, E.F., Olsen, G.J., and Pace, N.R. 1988: Phylogenetic group-specific oligodeoxynucleotide probes for identification of single microbial cells. J. Bacteriol., 170, 720-726

Hahn, D., Amann, R.I., Ludwig, W., Akkermans, A.D.L., and Schleifer, K.H. 1992: Detection of microorganisms in soil after in situ hybridization with rRNA-targeted, fluorescently labelled oligonucleotides. J. Gen. Microbiol., 138, 879-887

Hahn, D., Amann, R.I., and Zeyer, J. 1993: Whole-cell hybridization of Frankia strains with fluorescenceor digoxigenin-labelled, $16 \mathrm{~S}$ rRNA-targeted oligonucleotide probes. Appl. Environ. Microbiol., 59, 17091716

Nishimura, M., Tsuda, A., and Kogure, K. 1995: Application of flow cytometry for measuring changes in intercellular RNA contents of marine bacteria. Bull. Jpn. Soc. Microbiol. Ecol., 10, 73-79

Ramsing, N.B., Kuhl, M., and Jorgensen, B.B. 1993: Distribution of sulfate-reducing bacteria, $\mathrm{O}_{2}$, and $\mathrm{H}_{2} \mathrm{~S}$ in photosynthetic biofilms determined by oligonucleotide probes and microelectrodes. Appl. Environ. Microbiol., 59, 3840-3849

Schleifer, K.H., Amann, R.I., Ludwig, W., Rothemund, C., Springer, N., and Dorn, S. 1992: Nucleic acid probes for the identification and in situ detection of pseudomonads. In Pseudomonas, Molecular Biology and Biotechnology, Ed. E. Galli, S. Silver, and B. Witholt, p. 127-134, American Society for Microbiology, Washington, D.C.

Someya, T. 1995: Three-dimensional observation of soil bacteria in organic debris with a confocal laser scanning microscope. Soil Microorg., 46, 61-69

Spring, S., Amann, R.I., Ludwig, W., Schleifer, K.H., van Gemerden, H., and Petersen, N. 1993: Dominating role of an unusual magnetotactic bacterium in the microaerobic zone of a freshwater sediment. Appl. Environ. Microbiol., 59, 2397-2403

Zimmermann, R., Iturriaga, R., and Birck, J.B. 1978: Simultaneous determination of the total number of aquatic bacteria and the number thereof involved in respiration. Appl. Environ. Microbiol., 36, 926-935 